\title{
Inhibitory Effects of Melicope ptelefolia Extract on Compound Action Potentials in Frog Sciatic Nerves and Its Possible Mechanism of Action \\ (Kesan Perencat Ekstrak Melicope ptelefolia pada Potensi Tindakan Sebatian dalam Saraf Skiatik Katak dan Tindakan Mekanisme Kemungkinan)
}

\author{
JASMine SiEW Min CHIA, AMMAR IZZATI AMIR RAMADAN, FARIHAH HANANi GHAZALI, \\ Siong Jiun Wong, MoHd Roslan Sulaiman, TengKu AZAm SHAH TENGKU MoHamad, \\ MOHD KHAIRI HUSSAIN \& ENOCH KUMAR PERIMAL*
}

\begin{abstract}
Melicope ptelefolia is a medicinal plant from the Rutaceae, also known as 'tenggek burung' in Malaysia. Traditionally, natives ingest M. ptelefolia to treat a wide range of illnesses. This study aimed to investigate the effects of M. ptelefolia aqueous extract (MPAE) on compound action potentials (CAPS) in frog sciatic nerves and its mechanism involving the opioid receptors. The effects of MPAE on CAPS in frog sciatic nerves were examined using the AD Instrument Nerve Chamber. The frog sciatic nerves were dissected from the lumbar plexus to the knee of the frog and placed in Ringer's solution. Three treatment groups with different dosages (1,3 and $10 \mathrm{mg} / \mathrm{mL})$ of MPAE, including negative (vehicle) and positive control group ( $3 \mathrm{mg} / \mathrm{mL}$ of morphine) were tested on the frog sciatic nerves by placing them in a nerve organ chamber. Following this, the involvement of opioid receptors in the effects of MPAE on CAPs was investigated by using naloxone hydrochloride as a non-selective opioid receptor antagonist. Our results showed that the peak amplitudes of CAPS were significantly $(\mathrm{p}<0.001)$ reduced when treated with MPAE $(3$ and $10 \mathrm{mg} / \mathrm{mL})$ in frog sciatic nerves. The MPAEinduced CAPS inhibition was reversed when pre-treated with naloxone, suggesting the involvement of the opioidergic system. These results indicated the modulatory action of MPAE on nerve conduction, which may provide important leads in the development of new therapeutic drugs through the involvement of opioid receptors.
\end{abstract}

Keywords: Compound action potential; frog sciatic nerves; opioidergic; opioid receptors; Melicope ptelefolia

ABSTRAK

Melicope ptelefolia adalah sejenis tumbuhan ubatan daripada Rutaceae, juga dikenali sebagai 'tenggek burung' di Malaysia. Secara tradisinya, penduduk pribumi menggunakan M. ptelefolia untuk merawat pelbagai jenis penyakit. Kajian ini bertujuan untuk mengkaji kesan ekstrak akuas M. ptelefolia (MPAE) terhadap potensi tindakan sebatian (CAPS) dalam saraf skiatik katak dan mekanisme yang melibatkan reseptor opioid. Kesan MPAE pada CAPs saraf skiatik dikaji menggunakan AD Instrument Nerve Chamber. Saraf skiatik katak dibedah dari pleksus lumbar ke lutut katak dan diletakkan di dalam larutan Ringer. Sebanyak tiga kumpulan rawatan dengan dos yang berbeza (1, 3 dan $10 \mathrm{mg} / \mathrm{mL})$ MPAE, dengan kumpulan kawalan negatif (pembawa) dan positif (3 $\mathrm{mg} / \mathrm{mL}$ morfin) diuji pada saraf skiatik katak dengan meletakkannya dalam ruang organ saraf. Berikutan itu, penglibatan reseptor opioid dalam mekanisme MPAE menghalang CAP telah dikaji dengan menggunakan nalokson hidroklorida sebagai antagonis reseptor opioid yang tidak memilih. Hasil kajian kami menunjukkan bahawa puncak amplitud potensi tindakan sebatian telah berkurang dengan ketara ( $\mathrm{p}<0.001$ ) apabila dirawat dengan ekstrak akua M. ptelefolia (3 dan $10 \mathrm{mg} / \mathrm{mL}$ ) dalam saraf skiatik katak. Perencatan CAPs yang disebabkan oleh MPAE dibalikkan apabila saraf skiatik menerima pra-rawatan dengan nalokson mencadangkan penglibatan sistem opioidergik. Hasil kajian ini menunjukkan tindakan modulasi MPAE pada pengaliran sarafyang dapat memberikan petunjuk yang penting dalam perkembangan dadah terapeutik baru melalui penglibatan reseptor opioid.

Kata kunci: Melicope ptelefolia; opioidergik; potensi tindakan sebatian; reseptor opioid; saraf skiatik katak

\section{INTRODUCTION}

Excitation of nerve cells results in a momentary change in membrane potential, resulting in the propagation of nerve signals. This interaction between extracellular substance and intracellular medium is known as action potential (Bogatov et al. 2014). Compound action potential (CAP) is the combined propagation of nerve signals of a group of fibres of cell. Peripheral nerves produce CAPs in both proximal and distal sites in the presence of a stimulus. Measurements such as action potential amplitudes and conduction velocity in different nerve segments can be graphically analyzed from CAPs (Li 2015).

As modern medicine may manifest many undesirable side effects, more research on natural product is required. 
One of the natural products is Melicope ptelefolia which is a medicinal plant from the Rutaceae family, known as 'tenggek burung', 'pauh-pauh' and also 'cabang tiga' in Malaysia. This plant is claimed by the natives to treat fever, pain, wounds and itches (Karim et al. 2011). Previous studies have stated that $M$. ptelefolia leaf extract has antiinflammatory, analgesic and antinociceptive properties (Sulaiman et al. 2010). Inhibition of nerve conduction is one of the mechanisms on pain modulation. Therefore, M. ptelefolia may give inhibitory effect on CAPs as it has already shown antinociceptive properties.

In this study, naloxone hydrochloride was used as a non-selective opioid receptor antagonist to determine the involvement of opioid receptors in the effects of MPAE. The opioid receptor subtypes namely $\mathrm{Mu}(\mu)$, Delta $(\delta)$, and Kappa $(\kappa)$, are often targeted for pain treatments (AlHasani \& Bruchas 2011). Activation of opioid receptors typically inhibits transmission of action potentials. Thus, usage of an opioid receptor antagonist often provides preliminary results on whether a compound acts through opioid receptors. Excited neuronal transmission of action potentials will occur at a constant rate if a certain compound elicits its effects without involvement of opioid receptors.

However, to the best of our knowledge, there is still no report examining the actions of Melicope ptelefolia aqueous extract (MPAE) on nerve conduction. Therefore, this study aimed to investigate the effects of MPAE on CAPs in frog sciatic nerves and its mechanism involving the opioidergic system. The results of this study will highlight the underlying activity of $M$. ptelefolia extract as an analgesic emphasising the use of natural products for clinical practice.

\section{MATERIALS AND METHODS}

\section{PLANT EXTRACTION}

Fresh leaves of $M$. ptelefolia were bought from Pasar Borong, Serdang, Selangor, Malaysia. The fresh leaves were identified and authenticated by a resident botanist through comparison with herbarium specimens of $M$. ptelefolia (SK 3071/16) kept at the Mini Herbarium, Institute of Bioscience, Universiti Putra Malaysia (UPM). The aerial parts of the plants, including the stems and leaves were washed and oven-dried for $48 \mathrm{~h}$ at $40^{\circ} \mathrm{C}$. Dried leaves were ground and stored at $-20^{\circ} \mathrm{C}$. The powdered leaves were heated at about $80^{\circ} \mathrm{C}$ with an extraction ratio of approximately 1:10 of distilled water. The MPAE was freeze-dried for 3 days and stored at $4{ }^{\circ} \mathrm{C}$ until further use.

\section{EXPERIMENTAL ANIMALS}

Rana catesbeiana frogs of either sex, weighing 200 to $300 \mathrm{~g}$, were used in this experiment. All the experiments were conducted in accordance with the ethical guidelines on animal experimentation. The protocols and procedures were approved by the Institutional Animal Care and Use Committee (IACUC) of Universiti Putra Malaysia (Ref: UPM/IACUC/AUP-U001/2017). All efforts were made to minimise animal suffering and the number of animals used.

\section{DRUG PREPARATION}

M.ptelefolia aqueous extract (MPAE) (1,3 and $10 \mathrm{mg} / \mathrm{mL}$ ) was used as treatment in this experiment. Vehicle group received a mixture of $95 \%$ normal saline and $5 \%$ Tween 20. Morphine ( $3 \mathrm{mg} / \mathrm{mL}, 10 \mathrm{mM}$ ) was used as the positive control. Naloxone hydrochloride $(0.1 \mathrm{mg} / \mathrm{mL}, 0.27 \mathrm{mM})$, a non-selective opioid receptor antagonist, was used to study the involvement of opioidergic system. Ringer's solution ( $\mathrm{NaCl}, 115.5 \mathrm{mM} ; \mathrm{KCl}, 2.0 \mathrm{mM} ; \mathrm{CaCl}_{2}, 1.8 \mathrm{mM} ; \mathrm{Na}_{2} \mathrm{HPO}_{4}$, $1.3 \mathrm{mM}$; and $\left.\mathrm{NaH}_{2} \mathrm{PO}_{4}, 0.7 \mathrm{mM}(\mathrm{pH}=7.0)\right)$ was used as temporary medium to keep the sciatic nerves before CAPs measurement procedures.

\section{EXPERIMENTAL DESIGN}

For the first set of experiment, the effects of MPAE on CAPS were evaluated whereas the involvement of the opioidergic pathway was investigated as the second set of experiment. The experimental timeline and treatment groups are as shown in Figure 1 and Table 1, respectively.

\section{PREPARATION OF FROG SCIATIC NERVES}

The method used for isolation and preparation of frog sciatic nerves was as previously described (Katsuki et al. 2006; Kosugi et al. 2010; Mizuta et al. 2008). Frogs were decapitated and then pithed; the sciatic nerves were dissected from the lumbar plexus to the knee. Throughout dissections, Ringer's solution was continuously applied to the nerves to keep it moist. Sciatic nerves were kept in Ringer's solution before measuring the CAPs.

\section{RECORDINGS OF CAPS FROM FROG SCIATIC NERVE}

CAPs were recorded using AD Instrument Nerve Chamber and LabTutor Software. The frog sciatic nerve was placed at the center of the chamber and the nerve was stimulated for recording of CAPs. The stimulation was started at 10 $\mathrm{mV}$ and measurements were recorded when the voltage reached $200 \mathrm{mV}$. CAPs were recorded before and after exposure to their respective experimental group treatments. The relative peak amplitude of CAPs was measured as the difference between baseline and CAPs peak levels (Yao et al. 2015).All procedures were performed quickly to avoid losing moisture of the sciatic nerve.

\section{EFFECTS OF MPAE ON CAPs}

The effects of MPAE were determined by using 5 experimental groups, which were the negative control (vehicle), MPAE treatment $(1,3$ and $10 \mathrm{mg} / \mathrm{mL})$ and positive control (morphine, $3 \mathrm{mg} / \mathrm{mL}$ ). The CAPs of frog sciatic nerves were recorded before each treatment 
A

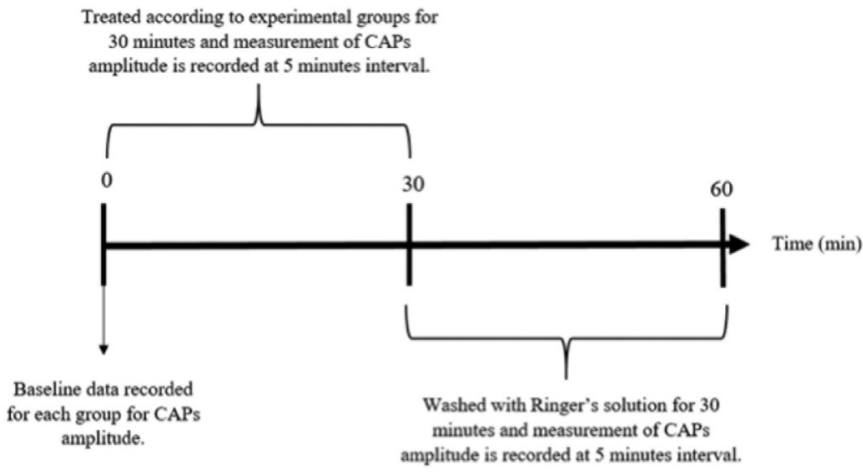

B

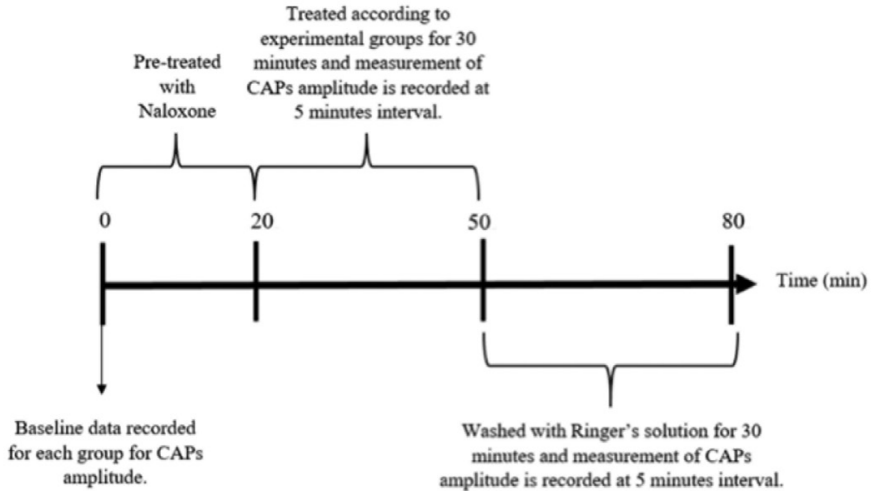

FIGURE 1. (A) Experiment 1: Investigating the inhibitory effects of MPAE on CAPs and (B) Experiment 2: Investigating the involvement of the opioidergic system in the inhibitory effects of MPAE

TABLE 1. Experimental treatment groups for sciatic nerves $(n=6)$ collected from a total of 27 animals

\begin{tabular}{lc}
\hline Experiment 1: Inhibitory effects of MPAE on CAPS & \\
\hline Vehicle & - \\
& $1 \mathrm{mg} / \mathrm{mL}$ \\
M.ptelefolia aqueous extract (MPAE) & $3 \mathrm{mg} / \mathrm{mL}$ \\
& $10 \mathrm{mg} / \mathrm{mL}$ \\
Morphine & $3 \mathrm{mg} / \mathrm{mL}$ \\
\hline Experiment 2: Involvement of opioidergic pathway & - \\
\hline Vehicle & $3 \mathrm{mg} / \mathrm{mL}$ \\
MPAE & $0.1 \mathrm{mg} / \mathrm{mL}$ \\
Naloxone hydrochloride & $3+0.1 \mathrm{mg} / \mathrm{mL}$ \\
MPAE + Naloxone hydrochloride
\end{tabular}

procedure. Sciatic nerves were soaked with respective treatments according to their experimental groups for $30 \mathrm{~min}$.

\section{INVOLVEMENT OF OPIOIDERGIC SYSTEM}

The involvement of opioidergic system was investigated using four experimental groups which were negative control (vehicle), MPAE treatment $(3 \mathrm{mg} / \mathrm{mL})$, naloxone hydrochloride $(0.1 \mathrm{mg} / \mathrm{mL})$ and MPAE $(3 \mathrm{mg} / \mathrm{mL})$ with naloxone hydrochloride group. Sciatic nerves $(n=6)$ were pre-treated with naloxone hydrochloride $(0.1 \mathrm{mg} / \mathrm{mL})$ for $20 \mathrm{~min}$ prior to soaking in MPAE $(3 \mathrm{mg} / \mathrm{mL})$ for $30 \mathrm{~min}$.

\section{DATA ANALYSIS}

Data are presented in relative CAPs amplitude with mean \pm S.E.M. and analysed using two-way ANOVA followed by Bonferonni's post-hoc test. The values were analysed using GraphPad Prism v5.0 software (GraphPad San Diego, CA) and the statistical significance was set at $p<0.05$.

\section{RESULTS}

Effects of treatments on CAPs were examined in a total of 54 sciatic nerves with average peak amplitudes of the 
CAPs of 25.0 $\pm 1.6 \mathrm{mV}$. Complete recovery of CAPs peak amplitude was achieved after washing out the sciatic nerves for $30 \mathrm{~min}$.

\section{EFFECTS OF Melicope ptelefolia AQUEOUS EXTRACT IN FROG SCIATIC NERVES CAPS}

The effects of MPAE on frog sciatic nerves were examined by soaking the nerves in three different dosages, which were 1,3 and $10 \mathrm{mg} / \mathrm{mL}$. Inhibitory effects of the three dosages of MPAE as shown in Figure 2, were compared with controls. Reduction in CAPs peak amplitude was dose-dependent when treated with MPAE at 1, 3 and 10 $\mathrm{mg} / \mathrm{mL}$, where 3 and $10 \mathrm{mg} / \mathrm{mL}$ showed almost similar inhibition to CAPs peak amplitude. MPAE effects at $3 \mathrm{mg} /$ $\mathrm{mL}(14.2 \pm 1.4 \mathrm{mV} ; n=6)$ and $10 \mathrm{mg} / \mathrm{mL}(11.9 \pm 0.9 \mathrm{mV} ; n=6)$ were both significantly different $(p<0.001)$ after treatment when compared to vehicle $(21.0 \pm 2.2 \mathrm{mV} ; n=6)$.

In order to compare the effects of MPAE with other established analgesics, we investigated the effects of morphine $(3 \mathrm{mg} / \mathrm{mL})$ on CAPs peak amplitudes. Following exposure of sciatic nerves to morphine, CAPs amplitude significantly reduced $(12.3 \pm 0.7 \mathrm{mV} ; \mathrm{n}=6, P<0.001)$ as shown in Figure 2. The reduction of CAPs amplitude 30 min after exposure of respective treatments was not significantly different between MPAE ( 3 and $10 \mathrm{mg} / \mathrm{mL}$ ) and morphine $(3 \mathrm{mg} / \mathrm{mL})$ where the CAPs amplitudes were $14.2 \pm 1.4 \mathrm{mV}, 11.9 \pm 0.9 \mathrm{mV}$ and $12.3 \pm 0.7 \mathrm{mV}$, respectively.

Traces of the nerves soaked in $3 \mathrm{mg} / \mathrm{mL}$ of MPAE reducing the CAPs amplitude were compared to control (vehicle) as shown in Figure 3 demonstrates the relative CAPs amplitudes of MPAE $(3 \mathrm{mg} / \mathrm{mL})$ with maximal reduction effects were observed after 30 min of treatment (Figure 4). After the washing process, CAPs increased and returned to normal as the control after $60 \mathrm{~min}$.

\section{EFFECT OF OPIOID RECEPTOR ANTAGONIST IN FROG SCIATIC NERVES CAPS}

Naloxone hydrochloride, a non-specific opioid receptor antagonist, was used to determine the involvement of the opioidergic system in the MPAE-induced reduction of CAPs amplitude. Traces between the control, naloxone and naloxone with MPAE were compared between groups (Figure 5). Pre-treatment with naloxone alone did not significantly affect the CAPs. As shown in Figure 6, the reversible inhibition of MPAE at $3 \mathrm{mg} / \mathrm{mL}$ occurred in the presence of an opioid receptor antagonist. Following exposure to naloxone $(0.1 \mathrm{mg} / \mathrm{mL})$ for $20 \mathrm{~min}$ with MPAE treatment $(21.9 \pm 1.5 \mathrm{mV} ; n=6)$, the CAPs amplitude was significantly different from results obtained by treatment of MPAE alone $(14.2 \pm 1.4 \mathrm{mV} ; n=6, p<0.001)$.

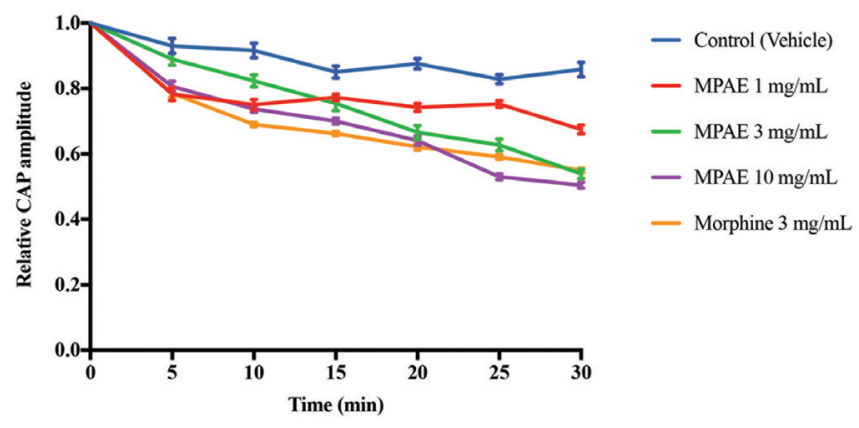

FIGURE 2. Changes in relative CAPs amplitudes of sciatic nerves in control, Melicope ptelefolia aqueous extract (MPAE) at 1,3 and $10 \mathrm{mg} / \mathrm{mL}$ and morphine treated groups $30 \mathrm{~min}$ following soaking. Each point represented CAPs peak amplitude following exposure to respective treatment, relative to values obtained prior to soaking, in six sciatic nerves

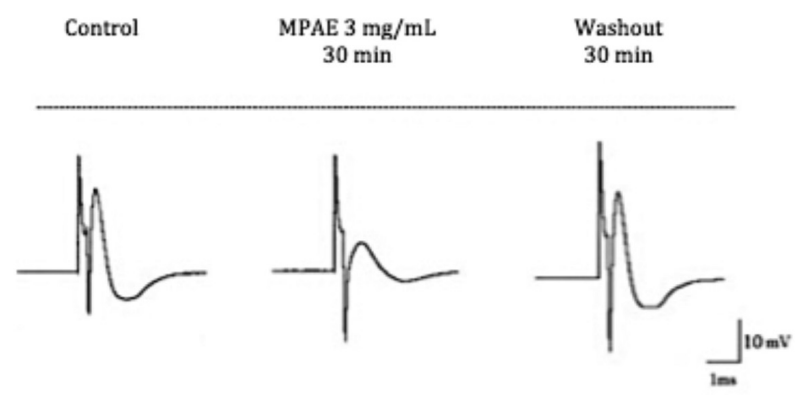

FIGURE 3. Comparison of CAPs amplitude curves between control and MPAE ( $3 \mathrm{mg} / \mathrm{mL}$ ) treatment $30 \mathrm{~min}$ after soaking. The MPAE curve obtained at $30 \mathrm{~min}$ has lower peak amplitude compared to the control, with the peak returning to normal after 30 min of washing 


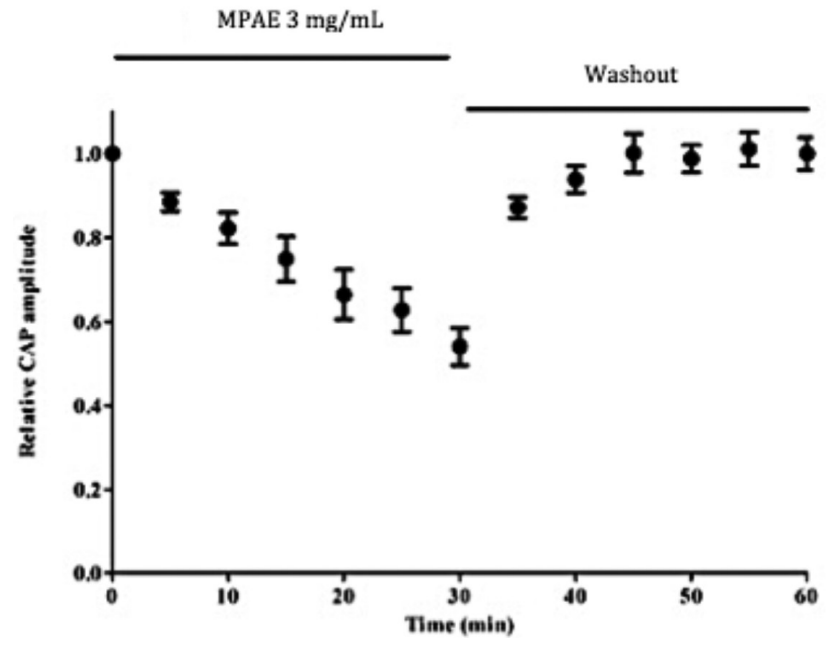

FIGURE 4. Average time course changes in CAPs peak amplitudes from sciatic nerves soaked in MPAE ( $3 \mathrm{mg} /$ $\mathrm{mL}$ ) over a period of $60 \mathrm{~min}$. After the washing process, the relative CAP amplitudes returned to normal at $60 \mathrm{~min}$. Each point represented CAPs peak amplitude following exposure to MPAE ( $3 \mathrm{mg} / \mathrm{mL}$ ) and washing, relative to values obtained prior to soaking, in six sciatic nerves

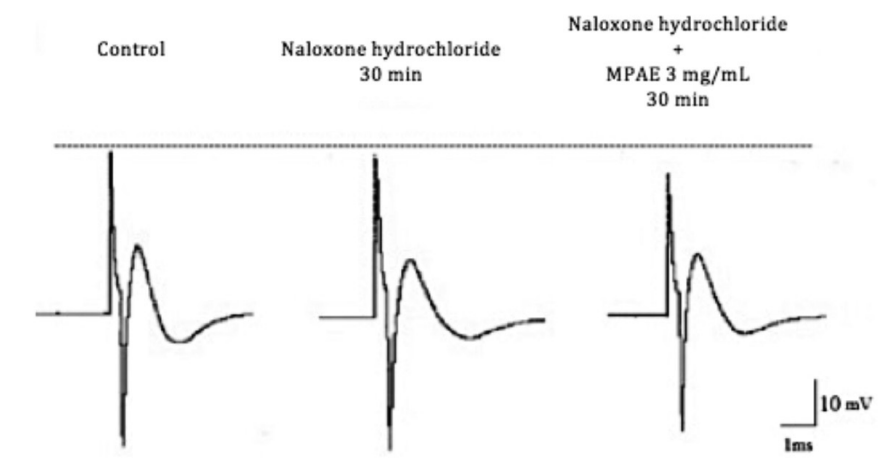

FIGURE 5. Comparison of CAPs amplitude curves between control, naloxone hydrochloride and naloxone hydrochloride pre-treated prior to MPAE $(3 \mathrm{mg} / \mathrm{mL}) 30 \mathrm{~min}$ after soaking. Exposure of the sciatic nerves to naloxone hydrochloride, a non-selective opioid receptor antagonist, prevented the inhibitory effects of MPAE on CAPs peak amplitude

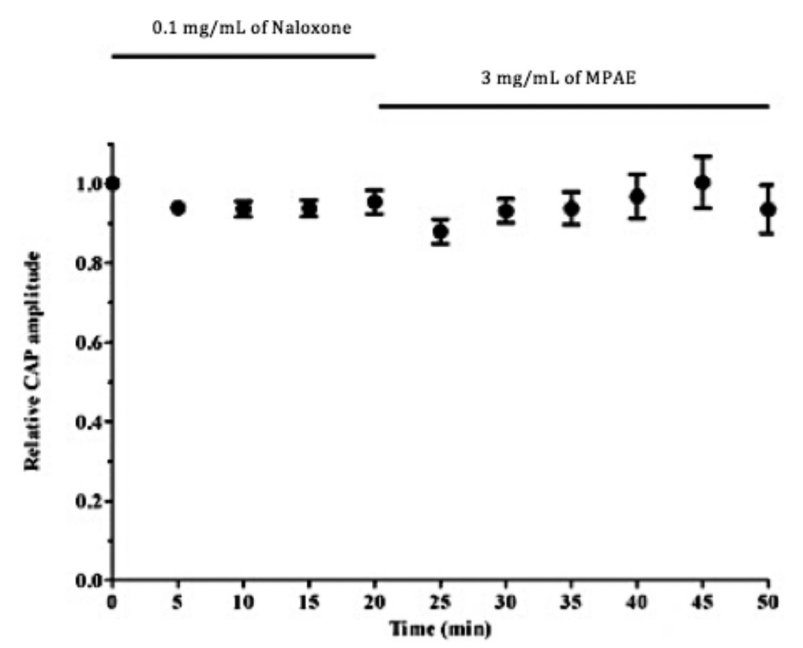

FIGURE 6. Average time course changes in CAPs peak amplitudes from sciatic nerves pre-treated with naloxone hydrochloride, a non-selective opioid receptor antagonist, prior to soaking with MPAE $(3 \mathrm{mg} / \mathrm{kg})$ over a period of $60 \mathrm{~min}$. Exposure to naloxone 20 min prior to treatment reverses the inhibitory effect of MPAE to CAPs peak amplitude. Each point represented CAPs peak amplitude following exposure to naloxone and $\operatorname{MPAE}(3 \mathrm{mg} / \mathrm{mL})$, relative to values obtained prior to soaking, in six sciatic nerves 


\section{DISCUSSION}

This study was carried out to investigate the effects of MPAE on CAPs in frog sciatic nerves, tested with three different dosages. To ensure absence of error or bias in recording of CAPs amplitudes, the setup was tested daily before recording by placing the filter paper soaked with Ringer's solution. The M. ptelefolia aqueous extract (MPAE) was dissolved in $95 \%$ of normal saline and $5 \%$ of Tween 20 . The sciatic nerves treated with vehicle were recorded and acted as the negative control to ensure the inhibition of CAPS during MPAE treatment was caused by the extract itself.

This study was the first to show the effects of MPAE on nerve conduction through inhibition on CAPs amplitudes, which was dose-dependent in the range of 1 to $10 \mathrm{mg} / \mathrm{mL}$. Based on the results, CAPs gradually decreased across the period of soaking in all three dosages of MPAE. The sciatic nerves soaked in $10 \mathrm{mg} / \mathrm{mL}$ of MPAE gave the maximal inhibition on CAPs at 30 min with $50 \%$ inhibition whereas MPAE at $3 \mathrm{mg} / \mathrm{mL}$ had almost $50 \%$ inhibition on CAPs. Morphine $(3 \mathrm{mg} / \mathrm{mL}$ ) was significantly different when compared to vehicle, where a $40 \%$ reduction of CAPs was observed $(p<0.001)$. As the effects of $3 \mathrm{mg} / \mathrm{mL}$ of MPAE on CAPs were as strong as $10 \mathrm{mg} / \mathrm{mL}$, therefore $3 \mathrm{mg} / \mathrm{mL}$ of MPAE was chosen as the optimum dose for Experiment 2.

The effect of MPAE inhibition on CAPs could occur through nonspecific membrane bilayer interactions or through inhibition of tetraethylammonium(TEA)-sensitive $\mathrm{K}^{+}$channels and/or tetrodotoxin(TTX)-sensitive voltagegated $\mathrm{Na}^{+}$channels (Mizuta et al. 2008). The intensity of CAPs amplitude relies on the influx of $\mathrm{Na}^{+}$, efflux of $\mathrm{K}^{+}$and the resting potential level. The involvement of these ion channels could be observed from the CAPs graph whereby the rise period of action potential represents $\mathrm{Na}^{+}$-dependent parameters and repolarisation period represents $\mathrm{K}^{+}$effluxdependent parameters (Pandey \& Deshpande 2012). Further studies on how MPAE interacts with $\mathrm{Na}^{+}$and $\mathrm{K}^{+}$ channels should be conducted.

Our results showed that the effects of MPAE on sciatic nerves CAPS were inhibited when pre-treated with naloxone $(0.1 \mathrm{mg} / \mathrm{mL})$. As there was no significant difference in CAPs amplitudes across the time (0-50 $\mathrm{min})$, opioid receptors may be involved in the inhibitory effects of MPAE on nerve conduction. A study by Uemura et al. (2014) showed that analgesics exert their antinociceptive effects through inhibition of nerve action potential conduction. Previous study on the M. ptelefolia extract in an animal model of antinociception exhibited analgesic properties (Sulaiman et al. 2010). The ability of MPAE to reduce CAPs amplitude is therefore correlated with inhibition of nerve conduction, which indirectly alleviates pain (Sandkühler 2000). The opioidergic system is one of the highly important pain modulatory systems in the pain pathway and the effects of MPAE on CAPS amplitude may have been mediated by opioid receptors. Previous studies on opioids showed reduction on CAPs amplitudes due to the presence of opioid receptors on nerve fibres (Fields et al. 1980; Gissen et al. 1987;
Jaffe \& Rowe 1996). The inhibitory effect of morphine is highly sensitive to the presence of naloxone, which antagonised the CAPs amplitude reduction, demonstrating the involvement of opioid receptors (Jurna \& Grossman 1977).

There are various pathways and receptors that may cause an effect towards CAPs. In this paper, we showed that MPAE activity on nerve conduction was influenced by opioid receptors. Exogenous opioids for example, do not exert its inhibitory effects solely through opioid receptors. Güven et al. (2005) reported that tramadol, a centrally acting opioid, has low affinity to opioid receptors. Instead, tramadol inhibits peripheral nerve conduction via blockade of $\mathrm{Na}^{+}$and $\mathrm{K}^{+}$channels. Thus, it is possible that other receptors and channels influence MPAE-induced CAPS inhibition.

\section{CONCLUSION}

In summary, the present study showed that M. ptelefolia aqueous extract (MPAE) has the ability to modulate nerve conduction by inhibiting CAPs. Inhibitory mechanism, particularly through the involvement of the opioidergic system was demonstrated with $3 \mathrm{mg} / \mathrm{mL}$ of MPAE. Our findings indicated that MPAE has high potential as a naturally sourced analgesic where it could serve in both nutraceutical and drug industries.

\section{ACKNOWLEDGEMENTS}

The authors thank the Faculty of Medicine and Health Sciences, Universiti Putra Malaysia, and the Physiology Laboratory for providing the necessary support for the study. This project was supported by Universiti Putra Malaysia under the Putra Young Initiative (IPM) Grant (GP-IPM/2014/9433700).

\section{REFERENCES}

Al-Hasani, R. \& Bruchas, M.R. 2011. Molecular mechanisms of opioid receptor-dependent signaling and behavior. Anesthesiology 115(6): 1363-1381.

Bogatov, N.M., Grigoryan, L.R., Ponetaeva, E.G. \& Sinisyn, A.S. 2014. Calculation of action potential propagation in nerve fiber. Progress in Biophysics \& Molecular Biology 114(3): 170-174.

Fields, H.L., Emson, P.C., Leigh, B.K., Gilbert, R.F. \& Iversen, L.L. 1980. Multiple opiate receptor sites on primary afferent fibres. Nature 284(5754): 351-353.

Gissen, A.J., Gugino, L.D., Datta, S., Miller, J. \& Covino, B.G. 1987. Effects of fentanyl and sufentanil on peripheral mammalian nerves. Anesthesia \& Analgesia 66(12): 12721276.

Güven, M., Mert, T. \& Günay, I. 2005. Effects of tramadol on nerve action potentials in rat: Comparisons with benzocaine and lidocaine. International Journal of Neuroscience 115(3): 339-349.

Jaffe, R.A. \& Rowe, M.A. 1996. A comparison of the local anesthetic effects of meperidine, fentanyl, and sufentanil on dorsal root axons. Anesthesia \& Analgesia 83(4): 776-781. 
Jurna, I. \& Grossman, W. 1977. The effect of morphine on mammalian nerve fibres. European Journal of Pharmacology 44(4): 339-348.

Karim, A., Shahrim, M., Nasouddin, S.S., Othman, M., Mohd Adzahan, N., Hussin, S.R. \& Shaari, K. 2011. Consumers knowledge and perception towards Melicope ptelefolia (Daun Tenggek Burung): A preliminary qualitative study. International Food Research Journal 18(4): 1481-1488.

Katsuki, R., Fujita, T., Koga, A., Liu, T., Nakatsuka, T., Nakashima, M. \& Kumamoto, E. 2006. Tramadol, but not its major metabolite (mono - O - demethyl tramadol) depresses compound action potentials in frog sciatic nerves. British Journal of Pharmacology 149(3): 319-327.

Kosugi, T., Mizuta, K., Fujita, T., Nakashima, M. \& Kumamoto, E. 2010. High concentrations of dexmedetomidine inhibit compound action potentials in frog sciatic nerves without alpha(2) adrenoceptor activation. British Journal of Pharmacology 160(7): 1662-1676.

Li, J. 2015. Molecular regulators of nerve conduction - Lessons from inherited neuropathies and rodent genetic models. Experimental Neurology 267: 209-218.

Mizuta, K., Fujita, T., Nakatsuka, T. \& Kumamoto, E. 2008. Inhibitory effects of opioids on compound action potentials in frog sciatic nerves and their chemical structures. Life Sciences 83(5): 198-207.

Pandey, A.K. \& Deshpande, S.B. 2012. Bisphenol A depresses compound action potential of frog sciatic nerve in vitro involving $\mathrm{Ca}(2+)$-dependent mechanisms. Neuroscience Letters 517(2): 128-132.

Sandkühler, J. 2000. Learning and memory in pain pathways. Pain 88(2): 113-118.
Sulaiman, M.R., Mohd Padzil, A., Shaari, K., Khalid, S., Shaik Mossadeq, W.M., Mohamad, A.S., Ahmad, S., Akira, A., Israf, D. \& Lajis, N. 2010. Antinociceptive activity of Melicope ptelefolia ethanolic extract in experimental animals. Journal of Biomedicine \& Biotechnology 2010: 937642.

Uemura, Y., Fujita, T., Ohtsubo, S., Hirakawa, N., Sakaguchi, Y. \& Kumamoto, E. 2014. Effects of various antiepileptics used to alleviate neuropathic pain on compound action potential in frog sciatic nerves: Comparison with those of local anesthetics. BioMed Research International 2014: 5402389.

Yao, L.H., Yu, H.M., Xiong, Q.P., Sun, W., Xu, Y.L., Meng, W., Li, Y.P., Liu, X.P. \& Yuan, C.H. 2015. Cordycepin decreases compound action potential conduction of frog sciatic nerve in vitro involving $\mathrm{Ca}(2+)$-dependent mechanisms. Neural Plasticity 2015: 927817.

Department of Biomedical Sciences, Faculty of Medicine and Health Sciences

Universiti Putra Malaysia

43400 Serdang, Selangor Darul Ehsan Malaysia

*Corresponding author; email: enoch@upm.edu.my

Received: 17 May 2018

Accepted: 15 May 2019 